\title{
ПОРІВНЯЛЬНА АНАТОМО-ІМУНОГІСТОХІМІЧНА ХАРАКТЕРИСТИКА СЕЛЕЗІНКИ ПРЕДСТАВНИКІВ КЛАСІВ ПТАХИ І ССАВЦІ
}

Вступ. Необхідними для оцінки імуноморфології селезінки є анатомо-імуногістохімічні дослідження, які дозволяють вивчити розподіл лімфроцитів залежно від ії мікроскопічної будови.

Мета дослідження - вивчити особливості розподілу Т- і В-лімфроцитів різних кластерів у селезінці залежно від анатомічної будови органа в представників класів Птахи і Ссавці.

Методи дослідження. Селезінку відбирали у клінічно здорових голуба, курки, кроля, свині у фразу морфоффункціональної зрілості. Матеріал фріксували в 10-12 \% розчині нейтрального фрормаліну, промивали 24-48 год, зневоднювали в спирті, заливали в парафрін і виготовляли гістозрізи на мікротомі МС-2 товщиною 4-6 мкм, фрарбували гематоксиліном Ерліха та еозином. Субпопуляції лімфроцитів $(C D 4,8,19,20)$ виявляли за допомогою мишачих моноклональних антитіл (DAKO, Данія). Візуалізацію проводили, використовуючи систему детекції DAKO EnVision FLEX+ (DAKO, Данія), з додатковим забарвлюванням гематоксиліном Майєра (DAKO, Данія) та перенесенням у середовище Eukitt (Німеччина).

Результати й обговорення. Форма селезінки не залежить від класу тварин: еліпсоподібна в курки та сильно видовжена у голуба, кроля, свині. Лімфоїдні вузлики ссавців, на відміну від птахів, мають у своїй будові мантійну і маргінальну зони та світлий центр. Лімфоїдна тканина селезінки хребетних тварин класів Птахи і Ссавці сорормована значною кількістю лімфоцитів з маркерами CD4+, CD8+, CD19+, CD20+. Такі субпопуляції лімфоцитів у червоній пульпі селезінки голуба, курки, кроля, свині розміщувались поодиноко й дифузно, в білій пульпі вони найчастіше утворювали ланцюги або скупчення. Серед популяцій В-лімфроцитів у кроля та свині домінували лімфоцити $C D 19+((83,69 \pm 8,74)$ i $(75,14 \pm 7,13)$ шт. на 1 ум. од. пл.

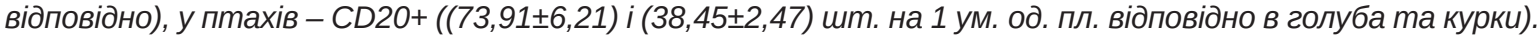
Імунорегуляторний індекс дорівнював 2,0 у курки, 1,85 у голуба, 1,82 у кроля, 1,71 у свині. Це вказує на розвиненість клітинних і гуморальних механізмів імунітету.

Висновок. У процесі еволюційного розвитку ускладнюється та вдосконалюється будова селезінки. Лімфроцити CD4+, CD8+ домінують у періартеріальній зоні та періартеріальних лімсроїдних піхвах, CD19+, CD20+ - у структурах лімфроїдних вузликів.

КЛЮчОВІ СЛОВА: селезінка; анатомія; імуногістохімія; Т- і В-лімфоцити; голуб; курка; кріль; свиня.

ВСТУП. Селезінка як перисреричний орган імунної системи має складну будову. Це зумовлено важливими і численними функціями, які вона виконує: фрільтраційною, очисною, імунною, кровотворною, депонувальною, крім того, займає центральне місце в контролі антигенного складу крові й початку імунної відповіді [1, 2]. Лімфоїдній тканині селезінки, як й імунній системі в цілому, властива унікальна здатність розпізнавати антигени і специсічно реагувати на них [2-6]. Сучасні імуногістохімічні методи дозволяють з'ясувати стромальні взаємозв'язки в органі [7] (с) Л. П. Горальський, О. Ф. Дунаєвська, Т. Я. Ярошенко, 2018. та проводити імунофенотипування лімфоцитів при патологічних станах організму і впливі різних чинників $[4,8]$. Імуногістохімічні дослідження виконують, як правило, у медицині та вже починають упроваджувати у ветеринарну практику для продуктивних тварин [2, 4]. Тому перспективними та необхідними для оцінки імуноморфології селезінки $€$ анатомо-імуногістохімічні дослідження, які дозволяють вивчити розподіл лімфоцитів залежно від її мікроскопічної будови у порівняльно-анатомічному ряді представників класів Птахи і Ссавці.

Мета дослідження - вивчити особливості розподілу Т- і В-лімфроцитів різних кластерів у 
селезінці залежно від анатомічної будови органа в представників класів Птахи і Ссавці.

МЕТОДИ ДОСЛІДЖЕННЯ. Селезінку відбирали у клінічно здорових тварин класів Aves Птахи (Gallus gallus, forma domestica L., 1758 домашня курка; Columbia livia G., 1789 - голуб сизий) та Mammalia - Ссавці (Oryctolagus cuniculus L., 1758 - кріль європейський; Sus scrofa, forma domestica L., 1758 - свиня домашня) господарств Житомирської області (СТВ “Птахівник”, ФГ “Миколай”, пОСТ "Надія", ТОВ “Профруна", ПА “Тетерів", ТОВ "Агрофрірма Брусилів"). Тварин підбирали за принципом аналогів за породою, віком, статтю, масою у фразу морфофункціональної зрілості селезінки кількістю 18 голів кожного виду. Матеріал фріксували в 10$12 \%$ розчині нейтрального фрормаліну, промивали впродовж 24-48 год, зневоднювали в спирті зростаючої міцності, заливали в парафрін за схемою, яку запропонували Л. П. Горальський і співавт. (2011) [9]. Гістозрізи виготовляли на санному мікротомі МС-2 товщиною 4-6 мкм, фарбували гематоксиліном Ерліха та еозином. Субпопуляції лімфроцитів (CD4, 8, 19, 20) виявляли за допомогою мишачих моноклональних антитіл (DAKO, Данія). Визначали їх розміщення, вміст (абсолютну і відносну кількість), кількісне співвідношення популяцій та імунорегуляторний індекс (IPI) як відношення кількості клітин CD4+ до кількості клітин CD8+ в полі зору мікроскопа (окуляр 10, об'єктив 40). Візуалізацію первинних антитіл проводили, використовуючи систему детекції DAKO EnVision FLEX+ (DAKO, Данія), з додатковим забарвлюванням гематоксиліном Майєра протягом 1-3 хв (DAKO, Данія) та перенесенням у середовище Eukitt (Німеччина). Препарати вивчали на мікроскопі "Olympus AX70" (Японія) із цисрровою відеокамерою "Olympus

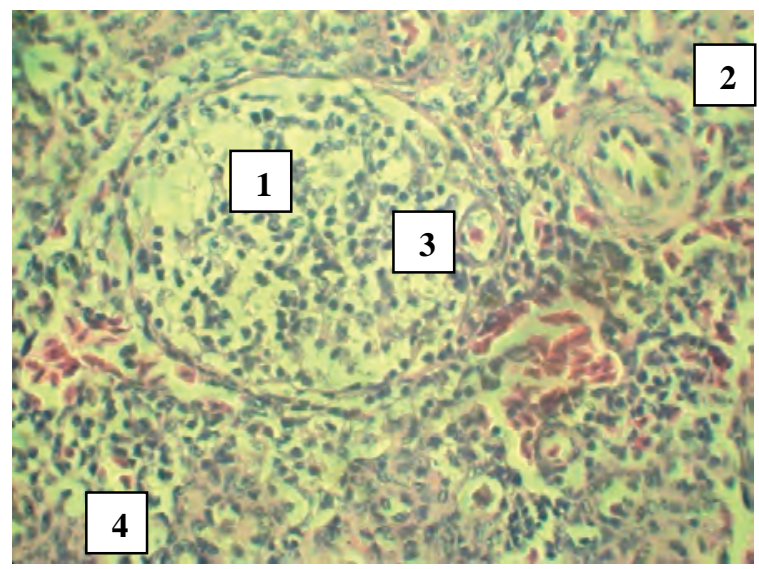

Рис. 1. Паренхіма селезінки голуба. Забарвлення гематоксиліном Ерліха та еозином. Збільшення ×80. Умовні позначення: 1 - ЛВ; 2 - ПАЛП; 3 - Паз; 4 - ЧП.
DP50", з'єднаною з ПК. Цифррові дані обробляли за допомогою програмного забезпечення Excel ("Microsoft", США) i STATISTICA 6.0 ("Statsoft", США). Експерименти виконано з дотриманням норм Європейської конвенції про захист хребетних тварин, що використовуються для дослідних та інших наукових цілей (Страсбург, 1986), ухвали I Національного конгресу з біоетики (Київ, 2001) і наказу МОЗ України від 23.09.2009 р. № 690 .

РЕЗУЛЬТАТИ Й ОБГОВОРЕННЯ. СеЛЕзінка у всіх досліджуваних тварин розташовувалась у лівому підребер'ї. У птахів вона розміщувалась у грудочеревній порожнині, у ссавців - черевній. Залежності її форми від класу тварин не виявили: еліпсоподібна в курки, вузька та сильно видовжена в решти тварин. Гістологічна будова селезінки представників класів Птахи і Ссавці має однакові структурні складові: опорно-скоротливий апарат та пульпу. Спільними ознаками є також поділ пульпи на білу (БП) і червону (ЧП), виявлення в білій пульпі лімфоїдних вузликів (ЛВ) з періартеріальною зоною (ПаЗ) та періартеріальних лімфоїдних піхв (ПАЛП). Найбільші відмінності у гістоструктурі спостерігали в будові ЛВ селезінки. У кроля та свині ЛВ чітко диференціювалися на світлий центр (СЦ), мантійну зону (Ман3), маргінальну зону (МЗ), яких у голуба і курки не було виявлено (рис. 1, 2).

Відповідно до анатомо-мікроструктурної організації, виявили певні імуногістохімічні особливості. Спільною характеристикою $є$ розміщення субпопуляції лімфроцитів із кластерами CD4+, CD8+, CD19+, CD20+ в пульпі селезінки голуба, курки, кроля і свині: поодиноко та дисрузо, найчастіше у вигляді ланцюгів або скупчення (рис. 3, 4).

Відмінності переважно стосувалися кількості та локалізації цих популяцій. Так, найбільшу

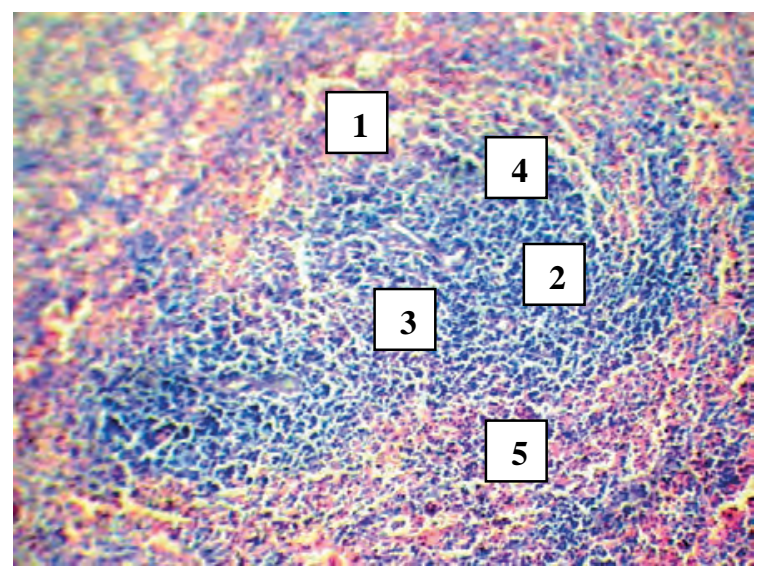

Рис. 2. Лімфоїдні вузлики селезінки голуба. Забарвлення гематоксиліном Ерліха та еозином. Збільшення $\times 70$. Умовні позначення: 1 - ЛВ; 2 - СЦ; 3 - Па3; 4 - Ман3; $5-$ M3. 


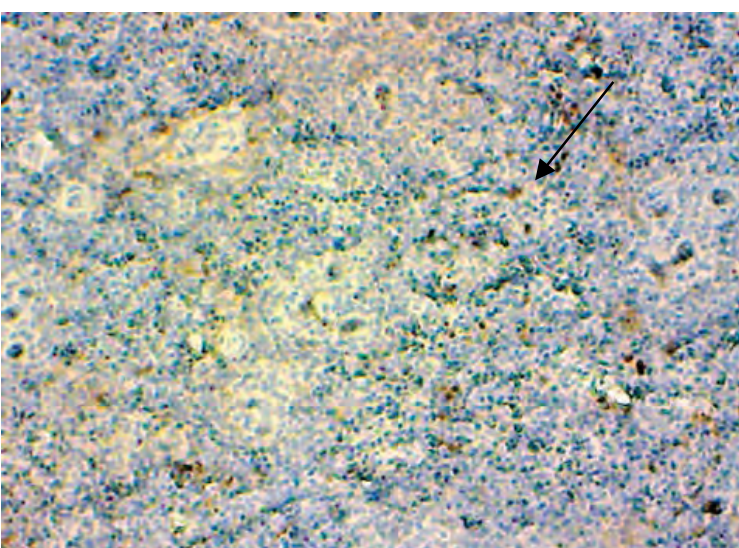

Рис. 3. Дифузне розташування лімфоцитів CD8+ у червоній пульпі селезінки курки. Забарвлення гематоксиліном Ерліха $з$ додатковим дофарбовуванням гематоксиліном Майєра. Збільшення ×120.

кількість лімфоцитів CD4+ виявлено у ПАЛПБП селезінки курки та голуба (рис. 5) від загальної кількості популяцій пульпи. У кроля та свині їх було майже вдвічі менше. Проте в ЧП селезінки і птахів, і ссавців кількість лімфоцитів CD4+ не перевищувала 9 шт. на 1 ум. од. пл. (рис. 5). У ссавців вони домінували в ЛВ, майже вдвічі менше їх було в ПАЛП (рис. 5). Оскільки ЛВ ссавців мають складну зональну будову, то й такі

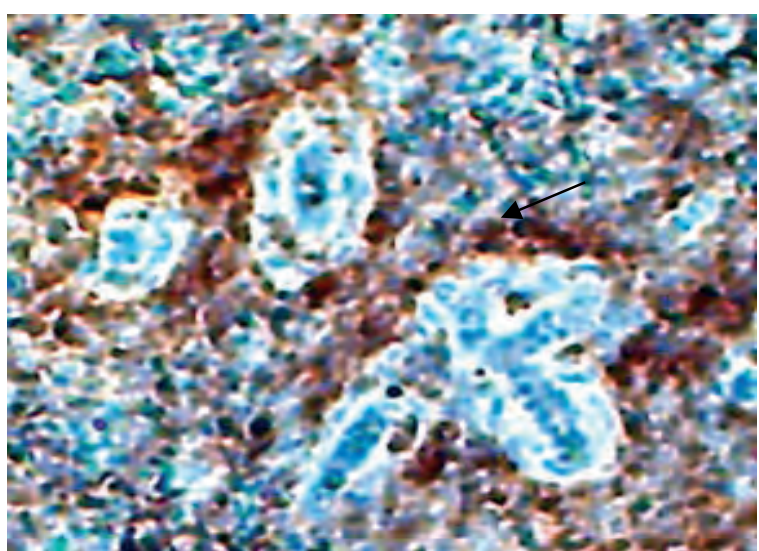

Рис. 4. Ланцюгове розташування лімфоцитів CD8+ навколо періартеріальних лімфоїдних піхв селезінки свині. Забарвлення гематоксиліном Ерліха з додатковим дофарбовуванням гематоксиліном Майєра. Збільшення ×120.

лімсроцити зазнали нерівномірного розподілу в них: найбільшу кількість виявили в ПаЗ, значну кількість - у СЦ, менше - в МЗ та незначну кількість - у Ман3 (рис. 6). У кроля визначили дещо вищий вміст лімфоциитів CD4+ порівняно зі свинею, що, можливо, зумовлено належністю селезінки кроля до імунного типу.

У ссавців лімсооцити CD8+ локалізувалися переважно в ЛВ, у птахів - у ПАЛП. Зокрема, у

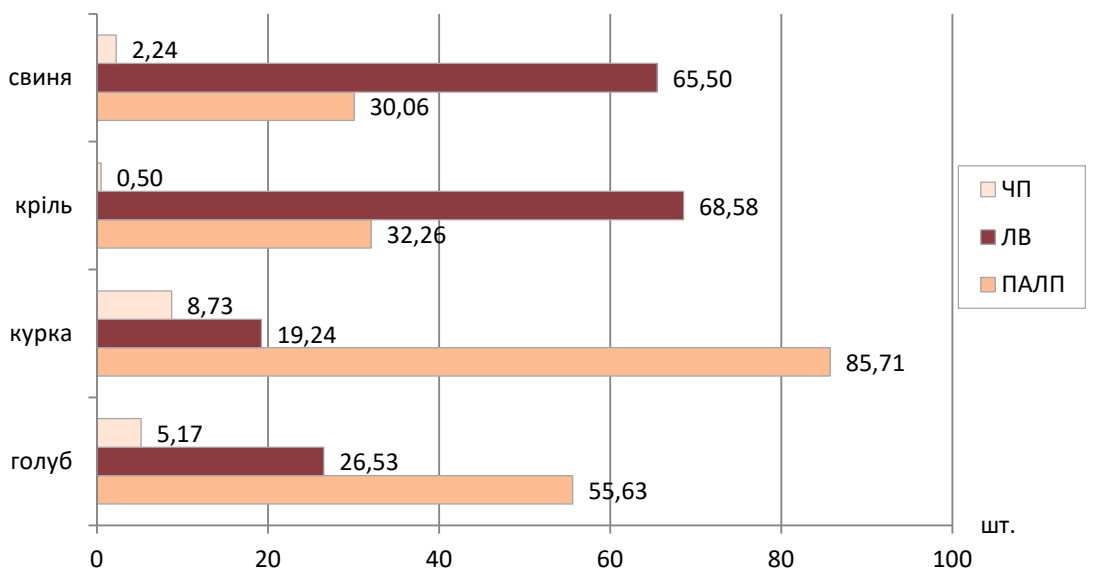

Рис. 5. Розподіл лімфроцитів CD4+ в селезінці птахів та ссавців.

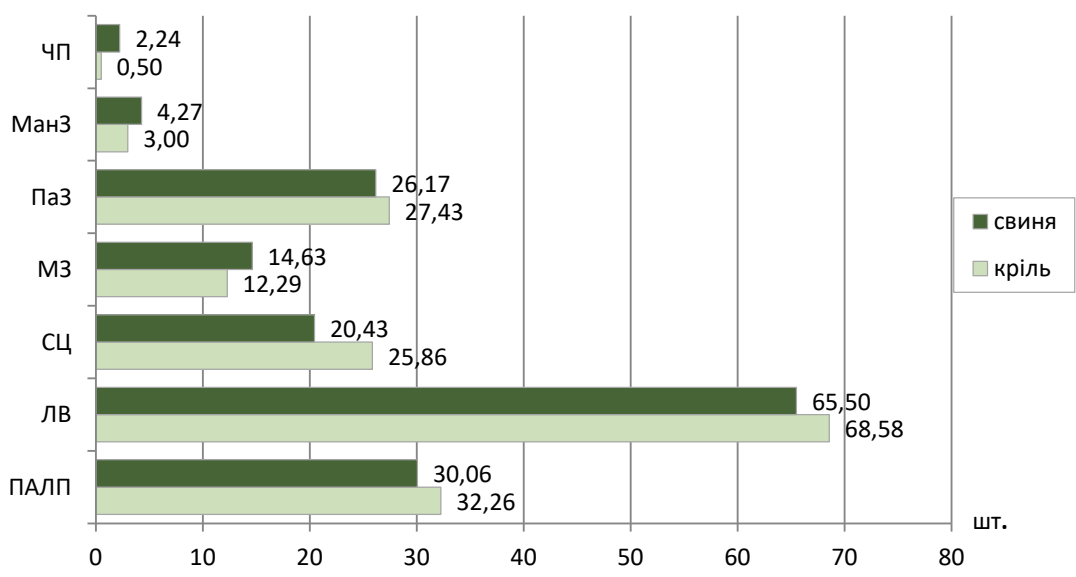

Рис. 6. Розподіл лімфроцитів CD4+ в селезінці ссавців. 
ПАЛП БП їх кількість становила 60,97 \% у голуба та $76,81 \%$ у курки, решта (30,73 і 15,93 \% відповідно) - у ЛВ БП. У ЛВ кроля відносна кількість лімфоцитів CD8+ складала 74,5 \%, у свині - 60,28 \%, тоді як у ПАЛП вона була значно нижчою - 24,51 та 38,1 \% відповідно. У чП селезінки їх вміст не перевищував 4,45 \% у голуба, 2,8 \% - у курки, 1,0 \% -у кроля та 1,62 \% у свині від загальної кількості популяцій. При цьому IPI пульпи селезінки найбільшим був у голуба, а найменшим - у свині (рис. 7). За даними інших наукових досліджень, IPI у курей становив 1,76 0,05 , що суттєво не відрізнялося від наших результатів [4].

Лімсроцити CD19+ були сконцентровані у ЛВ селезінки всіх досліджуваних тварин, найбільше їх виявили у кроля, найменше - в голуба (рис. 8). Серед популяцій В-лімфоцитів, за результатами наших імуногістохімічних досліджень, переважали лімфоцити CD20+ порівняно із CD19+: в зонах ПАЛП селезінки курки такі клітини займали 43,65 \%, у голуба - 18,0 \%. У кроля і свині лімфоцити CD20+ були розподілені майже однаково (13,2 та 13,0 \% відповідно), але найбільше вони були сконцентровані в ЛВ ссавців $86,08 \%$ у кроля і 76,96 \% у свині.

Встановлено, що в Т-залежній зоні селезінки (ПАЛП, ПаЗ) переважали лімфроцити популяцій

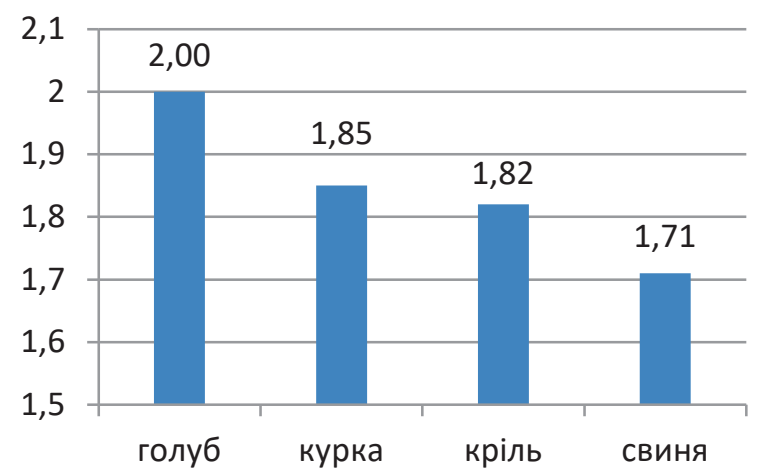

Рис. 7. Імунорегуляторний індекс селезінки пойкілотермних тварин.

CD4+, менше в 1,7-2 рази виявляли CD8+ у всіх досліджуваних тварин. У зовнішніх ділянках таких зон більш поліморснний склад, наявні популяції В-лімфоцитів. Світлий центр, мантійна зона і маргінальна зона лімфоӧдного вузлика $€$ Т-незалежною зоною, тому тут розміщуються В-лімфоцити та невелика кількість Т-лімфоцитів, серед яких переважають CD4+, у меншій кількості-CD8+. Особливістю M3 $є$ різноманітний популяційний склад лімфоцитів, адже в ній відбувається кооперативна взаємодія Т- і В-лімсроцитів [2, 10]. Ми виявили Т-лімсооцити CD8+ в ЧП селезінки, на що вказують й інші науковці [4].

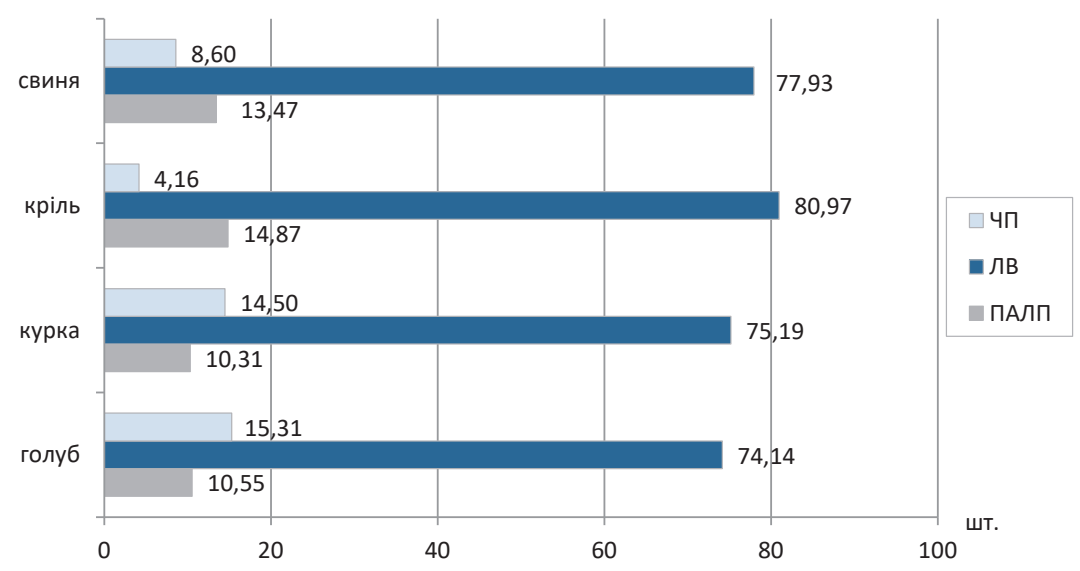

Рис. 8. Розподіл лімфоцитів CD19+ в селезінці птахів та ссавців, \%.

ВИСНОВКИ. Форма селезінки не має класової залежності: в курки вона еліпсоподібна, у решти тварин - вузька та сильно видовжена. У ссавців лімфоїдні вузлики складнішої будови: чітко дисреренціюються світлий центр, мантійна і маргінальна зони. За результатами імуногістохімічних досліджень встановлено, що лімфоїдна тканина селезінки хребетних тварин класів Птахи і Ссавці сфрормована значною кількістю лімфоцитів з маркерами CD4+, CD8+, CD19+, CD20+. Такі субпопуляції лімфоцитів у червоній пульпі селезінки тварин розміщуються поодино- ко й дисузно, в білій пульпі вони найчастіше утворюють ланцюги або скупчення. Серед популяцій В-лімсроцитів у ссавців домінують лімсроцити CD19+, у птахів - CD20+. Імунорегуляторний індекс дорівнює 2,0 у курки, 1,85 у голуба, 1,82 у кроля, 1,71 у свині. Це вказує на розвиненість клітинних і гуморальних механізмів імунітету.

Перспективи подальших досліджень. Зосередимо увагу на імуногістохімічному вивченні розміщення в селезінці тварин інших субпопуляцій лімфоцитів. 


\section{СПИСОК ЛІТЕРАТУРИ}

1. Bronte $\mathrm{V}$. The spleen in local and systemic regulation of immunity / V. Bronte, M. J. Pittet // Immunity. 2013. - 39, No. 5. - P. 806-818. DOI:10.1016/j. immuni.2013.10.010.

2. Панікар І. І. Морфологія та імуногістохімія органів імуногенезу свиней у період постнатальної адаптації : монограсрія / І. І. Панікар, Л.П. Горальський, Н. Л. Колеснік. - Полтава, 2015. - 258 с.

3. Касиева Г. К. Сравнительные иммуногистохимические исследования лимсратических узлов и селезенки крупного рогатого скота / Г. К. Касиева // Аграр. вестн. Верхневолжья. - 2015. - № 2 (11). - С. 13-18.

4. Гуральська С. В. Імуногістохімічна характеристика субпопуляцій лімсоцитів у селезінці курей при вакцинації їх проти інфекційного бронхіту / С. В. Гуральська // Наук. вісн. Львів. нац. ун-ту ветеринарної медицини та біотехнологій ім. С. 3. Ґжицького. 2016. - 16, № 3 (70). - С. 62-66.

5. Brinza L. Immune signatures of protective spleen memory CD8 T cells / L. Brinza // Scientific Reports. 2016. DOI: 10.1038/srep37651.

6. Schneider Z. Overexpression of bovine Fcrn in mice enhances $\mathrm{T}$-dependent immune responses by amplifying $\mathrm{T}$ helper cell frequency and germinal center enlargement in the spleen / Z. Schneider // Frontiers in Immunology. - 2015. - 6. - P. 1-16. DOI: 10.3389/fimmu.2015.00357.

7. Морфологическая характеристика тимуса и селезенки при воздействии фракторов различного происхождения / А. Г. Кварацхелия, С. В. Клочкова, Д. Б. Никитюк, Н. Т. Алексеева // Журн. анатомии и гистопатологии. - 2016. - 5, № 3. - С. 77-83.

8. Xiaoxu Duana. Acute arsenic exposure induces inflammatory responses and CD4+ Tcell subpopulations differentiation in spleen and thymus with the involvement of MAPK, NF-kB, and Nrf2 / Nrf2 / Xiaoxu Duana // Molecular Immunology. - 2017. - Vol. 81. - P. 160-172.

9. Горальський Л. П. Основи гістологічної техніки і морфоорункціональні методи досліджень у нормі та при патології / Л. П. Горальський, В. Т. Хомич, О. І. Кононський. - Житомир : Полісся, 2011. - 212 с.

10. Федоровская Н. С. Иммуноморфологическая характеристика селезенки при цитопениях иммунного генезиса / Н. С. Федоровская, Д. А. Дьяконов. Киров : Аверс, 2013. - 101 с.

\section{REFERENCES}

1. Bronte, V., \& Pittet, M.J. (2013). The spleen in local and systemic regulation of immunity. Immunity, 39 (5), 806-818. doi:10.1016/j.immuni.2013.10.010.

2. Panikar, I.I., Horalskyi, L.P., \& Kolesnik, N.L. (2015). Morfolohiia ta imunohistokhimiia orhaniv imunohenezu svynei u period postnatalnoi adaptatsii: monohrafiia [Morphology and immunohistochemistry of organs of immunogenesis of pigs during postnatal adaptation: monograph]. Poltava [in Ukrainian].

3. Kasieva, G.K. (2015). Sravnitelnye immunogistokhimicheskie issledovaniya limfaticheskikh uzlov i selezenki krupnogo rogatogo skota [Comparative immunohistochemical studies of lymph nodes and cattle spleen]. Agrarnyy vestnik Verkhnevolzhia - Agrarian Newspaper of the Upper Volga Region, 2 (11), 13-18 [in Russian].

4. Huralska, S.V. (2016). Imunohistokhimichna kharakterystyka subpopuliatsii limfotsytiv u selezintsi kurei pry vaktsynatsii yikh proty infektsiinoho bronkhitu [Immunohistochemical characteristic of subpopulations of lymphocytes in the spleen of chickens during vaccination against infectious bronchitis]. Naukovyi visnyk Lvivskoho natsionalnoho universytetu veterynarnoi medytsyny ta biotekhnolohii im. S.Z. Hzhytskoho - Scientific Herald of the Lviv National University of Veterinary Medicine and Biotechnology by S.Z. Hzhytskyi, 16 (3), 62-66 [in Ukrainian].

5. Brinza, L., Djebali, S., Tomkowiak, M., Mafille, J., Loiseau, C., Jouve, P., ... Marvel, J. (2016). Immune signatures of protective spleen memory CD8 T cells. Scientific Reports, 6. doi: 10.1038/srep37651.
6. Schneider, Z., Jani, P., Szikora, B., Végh, A., Kövesdi, D., Iliás, A., ... Kacskovics, I. (2015). Overexpression of bovine Fcrn in mice enhances T-dependent immune responses by amplifying $T$ helper cell frequency and germinal center enlargement in the spleen. Frontiers in Immunology, 6, 4-16. doi: 10.3389/fimmu.2015.00357.

7. Kvaratskheliya, A.G., Klochkova, S.V., Nikityuk, D.B., \&Alekseyeva, N.T. (2016). Morfologicheskaya kharakteristika timusa i selezenki pri vozdeystvii faktorov razlichnogo proiskhozhdeniya [Morphological characteristics of thymus and spleen under the influence of factors of different origin]. Zhurnal anatomii i gistopatologii Journal of Anatomy and Histopathology, 5 (3), 77-83 [in Russian].

8. Xiaoxu, D., Shuang, G., Jinlong, L., Liuzhong, W., Yang, Z., Wei, L., ... Bing, L. (2017). Acute arsenic exposure induces inflammatory responses and CD4+ T-cell subpopulations differentiation in spleen and thymus with the involvement of MAPK, NF-kB, and Nrf2 / Nrf2. Molecular Immunology, 81, 160-172.

9. Horalskyi, L.P., Khomych, V.T., \& Kononskyi, O.I. (2011). Osnovy histolohichnoi tekhniky imorfofunktsionalni metody doslidzhen u normi ta pry patolohii [Fundamentals of histological technology and morphofunctional methods of research in norm and pathology]. Zhytomyr: Polissia [in Ukrainian].

10. Fedorovskaya, N.S., \& Dyakonov, D.A. (2013). Immunomorfologicheskaya kharakteristika selezenki pri tsitopeniyakhimmunnogogenezisa[Immunomorphological characteristics of the spleen under cytopenes of the immune genesis]. Kirov: Avers [in Russian]. 
л. п. Горальский ${ }^{1}$, О. Ф. Дунаевская ${ }^{1}$, Т. Я. Ярошенко ${ }^{2}$ ЖИТОМИРСКИЙ НАЦИОНАЛЬНЫЙ АГРОЭКОЛОГИЧЕСКИЙ УНИВЕРСИТЕТ ТЕРНОПОЛЬСКИЙ ГОСУДАРСТВЕННЫЙ МЕДИЦИНСКИЙ УНИВЕРСИТЕТ ИМЕНИ И. Я. ГОРБАЧЕВСКОГО

\section{СРАВНИТЕЛЬНАЯ АНАТОМО-ИММУНОГИСТОХИМИЧЕСКАЯ ХАРАКТЕРИСТИКА СЕЛЕЗЕНКИ ПРЕДСТАВИТЕЛЕЙ КЛАССОВ ПТИЦЫ И МЛЕКОПИТАЮЩИЕ}

\section{Резюме}

Вступление. Необходимыми для оценки иммуноморфологии селезенки являются анатомо-иммуногистохимические исследования, позволяющие изучить распределение лимфоцитов в зависимости от ее микроскопического строения.

Цель исследования - изучить особенности распределения T- и В-лимфоцитов разных кластеров в селезенке зависимо от анатомического строения органа в представителей классов Птицы и Млекопитающие.

Методы исследования. Селезенку отбирали у клинически здоровых голубя, курицы, кролика, свиньи в фразе морфоофункциональной зрелости. Материал фриксировали в 10-12 \% растворе нейтрального фрормалина, промывали 24-48 4, обезвоживали в спирте, заливали в парафрин и изготавливали гистосрезы на микротоме МС-2 толщиной 4-6 мкм, окрашивали гематоксилином Эрлиха и эозином. Субпопуляции лимсроцитов (CD4, 8, 19, 20) выявляли с помощью мышиных моноклональных антител (DAKO, Дания). Визуализацию проводили, используя систему детекции DAKO EnVision FLEX+ (DAKO, Дания), с дополнительным окрашиванием гематоксилином Майера (DAKO, Дания) и переносом в среду Еикіtt (Германия).

Результаты и обсуждение. Форма селезенки не зависит от класса животных: элипсовидная у курицы и сильно удлиненная у голубя, кролика, свиньи. Лимсроидные узелки млекопитающих, в отличие от птиц, имеют в своем строении мантийную и маргинальную зоны и светлый центр. Лимфроидная ткань селезенки позвоночных животных классов Птицы и Млекопитающие сфрормирована большим количеством лимороцитов с маркерами CD4+, CD8+, CD19+, CD20+. Такие субпопуляции лимфоцитов в красной пульпе селезенки голубя, курицы, кролика, свиньи размещались одиночно и дифрфузно, в белой пульпе они чаще образовывали цепи или скопления. Среди популяций В-лимфоцитов у кролика и свиньи доминировали

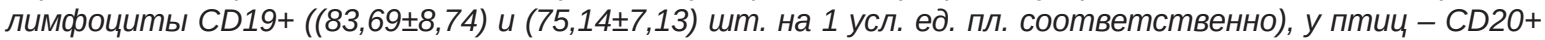
$((73,91 \pm 6,21)$ и $(38,45 \pm 2,47)$ шт. на 1 усл. ед. пл. соответственно у голубя и курицы). Иммунорегуляторный индекс равнялся 2,0 у курицы, 1,85 у голубя, 1,82 у кролика, 1,71 у свиньи. Это указывает на развитость клеточных и гуморальных механизмов иммунитета.

Вывод. В процессе эволюционного развития усложняется и усовершенствуется строение селезенки. Лимфоциты CD4+, CD8+ доминируют в периартериальной зоне и периартериальных лимфроидных влагалищах, CD19+, CD20+- в структурах лимфоидных узелков.

КЛЮЧЕВЫЕ СЛОВА: селезенка; анатомия; иммуногистохимия; Т- и В-лимфоциты; голубь; курица; кролик; свинья.

L. P. Goralskiy ${ }^{1}$, O. F. Dunaievska ${ }^{1}$, T. Ya. Yaroshenko ${ }^{2}$ ZHYTOMYR NATIONAL AGROECOLOGICAL UNIVERSITY ${ }^{1}$ I. HORBACHEVSKY TERNOPIL STATE MEDICAL UNIVERSITY²

\section{COMPARATIVE ANATOMICALLY-IMMUNOHISTOCHEMICAL CHARACTERISTICS OF SPLEEN IN REPRESENTATIVES OF BIRDS AND MAMMALS CLASSES}

\section{Summary}

Introduction. The anatomical and immunohistochemical investigations are necessary for studying the immune morphology of the spleen. They allow discovering the distribution of lymphocytes, depending on its microscopic structure. Immunohistochemical studies are used in medicine and begin to be introduced into veterinary practice for productive animals.

The aim of the study - to investigate the distribution of T- and B-lymphocytes of different clusters in the spleen, depending on the anatomical structure of the organ in the representatives of the classes Birds and Mammals. 
Research Methods. The spleen was taken in clinically healthy pigeon, chicken, rabbit, and pigs in the phase of morphofunctional maturity. Then the biological materials were fixed in 10-12\% solution of neutral formalin, washed 24-48 hours, dehydrated in alcohol, poured into paraffin, and prepared histological sections on a microtome MS-2 (the thickness of 4-6 microns), stained with Hematoxylin Ehrlich and eosin. Subpopulations of lymphocytes (CD4, $8,19,20)$ were detected using murine monoclonal antibodies (DACO, Denmark). Visualization was performed using the DAKO EnVision FLEX+Detection System (DAKO, Denmark) with additional Mayer hematoxylin (DAKO, Denmark) and transfer to Eukitt (Germany).

Results and Discussion. Lymphoid nodules of mammals, in contrast to birds, have had in their structure a mantle and marginal zone and a bright centre. Lymphoid tissue of the spleen of vertebrate animals of the class Birds and Mammary was formulated with a significant number of lymphocytes with markers CD4+, CD8+. Such subpopulations of lymphocytes in the red pulp of the spleen of the pigeon, chicken, rabbit, and pig were placed singly and diffusely. They were often formed chains or clusters in the white pulp. Among the populations of

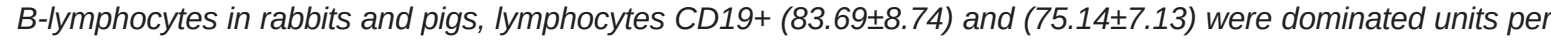
unit area respectively), in birds $-C D 20+(73.91 \pm 6.21)$ and $(38.45 \pm 2.47)$ units per unit area respectively, in the pigeon and chicken). The immunoregulatory index was equalled 2.0 at the chicken; 1.85 in the pigeon; 1.82 in rabbit; pigs 1.71. This indicates the development of cellular and humoral mechanisms of immunity.

Conclusion. In the process of evolutionary development, the complication and improvement of the structure of the spleen have occurred. CD4+, CD8+lymphocytes were dominated in the zone near the vessels and lymphoid sheaths near the vessels; and CD19+, and CD20+ were dominated in lymphoid nodule structures.

KEY WORDS: spleen; anatomy; immunohistochemistry; T- and B-lymphocytes; pigeon; chicken; rabbit; pig.

Отримано 29.10.18

Адреса для листування: О. Ф. Дунаєвська, Житомирський національний агроекологічний університет, Старий бульвар, 7, Житомир, 10002, Україна, e-mail: oksana_fd@ukr.net. 